\title{
Institutional Experience with Academic Reform: A Panel Discussion
}

\author{
John P. Evans \\ University of North Carolina \\ Michael Alden \\ University of Missouri \\ Kevin Anderson \\ University of Maryland
}

\author{
Carol Cartwright \\ Kent State University \\ Sidney McPhee \\ Middle Tennessee State University \\ Harvey Perlman \\ University of Nebraska
}

This paper consists of the transcripts of a panel discussion focusing on athletic directors', chancellors', and presidents' experiences with academic reform. The panel participants discuss a number of topics, including recent and past academic reform efforts, the process of implementing those initiatives, and the effects of those policies on student athletes and intercollegiate sport.

"JACK" EVANS: Good afternoon, ladies and gentlemen, and welcome to the Keynote 4 session of this year's scholarly colloquium. It's an opportunity to look at what we've done, what the results have been, and what the directions are for the future. The program committee members and I invited the folks on the podium to be a part of this panel because we wanted them to share their experiences with academic reform at their institutions, either as chancellor or president or athletic director, with this audience.

I would like to introduce each of the participants in the briefest possible way and then use the first question for the panel as an opportunity for them to talk more extensively about their initial involvement with academic reform. So let me move from my left to my right, your right to your left. At the far left is Mike Alden who is the director of athletics at the University of Missouri. Next is President Carol Cartwright who has been president at both Kent State and Bowling Green Universities. To my right is President Sidney McPhee, President of Middle Tennessee State University. Next is Chancellor Harvey Perlman, chancellor at the University of Nebraska - Lincoln. And to his right is Kevin Anderson who is the director of athletics at the University of Maryland.

\footnotetext{
Evans is Hettleman Professor of Business Emeritus, University of North Carolina at Chapel Hill, NC. Alden is Director of Athletics, University of Missouri, Columbia, MO. Anderson is Director of Athletics, University of Maryland, College Park, MD. Cartwright is President Emerita, Kent State University, Kent, OH. McPhee is President, Middle Tennessee State University, Murfreesboro, TN. Perlman is Chancellor, University of Nebraska - Lincoln, NE.
} 
I sent several questions that we might discuss to each of the members on this panel in advance. The first of those was a request that the panel members take three to five minutes to describe their first involvement or interaction with the current cycle of NCAA academic reform; that is, the new standards, the new metrics, the new consequences. This could be in the board of directors' approval of the initial design, your experience in your own institution's athletic program, or something else. But please use this as a point of departure.

For this first question, if it's all right to do it this way, President Cartwright, why don't we start with you?

CAROL CARTWRIGHT: Jack, thanks very much. Let me just share a little more about my background in higher education to give you a feel for how I've touched intercollegiate athletics over the years. I just retired after 45 years in higher education. I spent 21 years at a Big Ten institution, beginning as a faculty member. But I was also an academic administrator with responsibilities for the academic support for athletes. I spent three years in a Division II institution, and they were regular national champions, so it was a very strong program. The rest of my time has been at Kent State and Bowling Green, both in the Mid-American Conference, serving as president for both universities.

I have experience in the NCAA going back before the new governance structure, because I was one of two presidents on the NCAA Council which preceded the new federated governance through the board of directors and the board of directors. And I can tell you that, on academic issues, the dialogue in the room of the NCAA Council changed when one of the two presidents spoke up. It was obvious that presidential engagement was important.

I was a member of the very first board of directors of Division I as the new federated governance structure was formed. I represented the Mid-America Conference. I actually had a half a vote in that very first evolution of the new governance structure. I served on the board until 2005, the last two years, as chair of the executive committee.

I'm also a member of the Knight Commission on Intercollegiate Athletics and have been since 2000. So I was not part of the original Knight Commission. As the commission reconvened, I was asked to join and have been a member ever since.

I think Jack started with me, and I know he asked me to be on this panel because I was involved at the very beginning. I was at the NCAA board table as the academic reforms were being developed. I made a casual comment to Walt Harrison this morning as we were walking in the room for his keynote and noted that I was involved during the "sausage-making" phase of the reforms. By this I did not mean anything pejorative. I actually have seen sausage made. I was a statistician at a meat-packing plant between my second and third years of college, and I can tell you that very fine ingredients and excellent quality control can go into sausage making. What I meant to convey was that there were many ingredients and there was a lot of back and forth. There was a lot of debate, some very robust discussions, some highlights, and a few low lights, as a part of those early stages of discussions.

The reforms that were implemented in 2003 did not spring forth fully developed. So part of my role today is to share a little sense of the processes that were essential in getting the reform package developed, but are generally not widely known, because most of what's recorded and documented about the reforms comes as the final proposals were being approved and as implementation began. 
It's been noted frequently at this colloquium, and I think the presentations have been excellent in reminding us about this, that the history of the current era of academic reform is quite robust and has been well documented. I would also commend to your attention the centennial work that Joe Crowley produced for the NCAA called In the Arena, which gives a history of the organization and is fascinating in terms of the various eras of academic reform throughout more than 100 years of the NCAA.

So having been at the table from the beginning of the new federated governance structure, what's of the inside story? My memory for the specific details is not as clear now, many years later, but my recollection of the overall processes and the main principles and themes is really quite clear and remains quite strong.

Those now known as the BCS schools had the power on the board even at the beginning through the way the conferences were represented and the votes were distributed. But the board was absolutely united around two things in those early stages of reform discussions: (1) that the bar should be set high, that the reforms should be ambitious; and (2) that we should agree upon a set of values and principles, and that should be the touchstone against which every proposal that came forward was measured. There were no differences among us. There was no sense of "haves" and "have-nots" at that table. There was a united vision about the need for a high bar and the need for a package of reforms leading to improved graduation. We wanted our decisions to be data driven. If we weren't satisfied with the data and analysis that came with a proposal, we asked for more. And we felt like every proposal needed to pass this test: would it get a student closer to graduation? Ways to assure that students came prepared and then implementing proposals that enabled students to make progress to graduation were critically important to us as part of the overall package. The sense was that the closer you got to graduation-every semester achieved - was a further likelihood that you would eventually graduate.

We also felt that the reforms must provide adequate time to prepare. The period of readiness and a sense of staging-in and phasing-in was very important. For example, remember that we started with 11 core courses, and we are now at 16.

The board respected the process whereby proposals originated with a set of committees and then were approved eventually by what was then the Management Council before coming to the board for final action. The board respected that sense of process, but the board was not a rubber stamp. And this was actually a surprise to many people in the organization. There was a sense in the culture of the organization that what came through a process of approval from various other committees would be automatically approved by the board of directors. The board did its own due diligence. If there was a feeling that the data and analyses were not complete, the board asked for more. And the board conveyed a strong sense-you might call it tone at the top - that the bar should be set high. As I said, this was not part of the culture at the time, and there were more than a few times when members of various committees were not pleased that a proposal that they had supported was rejected by the board of directors and sent back for further work.

Now, the board didn't do the work itself. The board did not impose its own ideas, because the board understood that it did not have all of the necessary expertise. But the board also understood that it had a responsibility to uphold the values and principles and uphold the goals of an ambitious program of reform. So proposals were fairly regularly sent back to committees for additional work, and especially for ways to raise the bar higher. 
Now, just another half minute to make the story even more interesting. Remember that as these proposals were being developed, vetted, and approved, the board was also learning how to be a board. This was a brand-new form of governance for the NCAA. Board members were representing conferences, but they were also feeling their way on their roles, and the board and the NCAA staff together were developing practical ways to make the board work. At various times these two major themes, a new form of governance and a robust new package of academic reforms intertwined in some very interesting ways.

And let me leave the story there.

JACK EVANS: There may be some follow up to that.

CAROL CARTWRIGHT: Maybe.

JACK EVANS: Mike, would you like to go next?

MIKE ALDEN: Sure, Jack, thank you, and good afternoon, everyone. My name is Mike Alden, and I appreciated the opportunity that Jack had given me to join my colleagues here on the dais with you today.

I'm at the University of Missouri. I'm the athletics director at Mizzou. I've been there for 14-this is my 14th year at the University of Missouri. Currently I'm the chair of the NCAA Leadership Council. I'm also the past president of the Division I Athletics Directors Association and I'm the second vice president of NACTA as well too. So I've been fortunate to be involved in certain levels of assistance with the NCAA as well as some of our other organizations that are affiliated with college athletics. My other stops before I got to Mizzou, I was at the University of Pennsylvania as a football coach, and then I moved to Arizona State and to the University of New Mexico, Texas State University in San Marcos, Texas, and then I left San Marcos in 1998 to come to Mizzou.

And so, you know, as I look back on the academic reform efforts and when that was taking place several years ago now, I must tell you as the director of athletics at an institution in the Big 12 Conference, that probably wasn't the thing that was right on the tip of my tongue every day. It wasn't at the forefront of what I was looking at every day when I went to work.

You know, I was worried about how much money we were going to raise that day. I was worried about are we going to win a game. I was worried about the issue that we had at the previous game because maybe there was security issue or something like that that I needed to take care of. I was really disappointed that the popcorn sales were down for this particular game, so what we wanted to do obviously is put more ice in the soda and put a little bit more salt on top of that popcorn in concessions. So those are the things - and I'm saying that a little bit lightly_-but those are the things in a very serious topic, frankly, that I was worried about every single day.

But in our particular case, it was out of - spawned out of an issue that we had, a very high-profile issue on our campus with regards to a junior college, a community college transfer that had come to our school in the sport of basketball. And because of some issues that took place with that student-athlete transferring, we immediately began to take a look at 2-4 transfers, initial eligibility standards, and a number of other issues, and so I found myself in the middle of discussions 
with our faculty athletics representative, of course, our certification officer, our vice chancellor for enrollment management, as well as the director of admissions, who we work well together. But by virtue of an issue that we were dealing with on our campus, it almost coincided with a time when the board was taking a look at academic progress rates, initial eligibility standards, graduation success rates, and making sure that we were taking a look at how we could set the bar higher for what we were trying to do relative to our student-athletes. And so for us-I guess I'd say it's fortuitous now, you know, this many years away-is that because of an issue that we were dealing with on our campus, I automatically, almost immediately, became in tune with what we were trying to do on our campus to raise standards and to take a look at various types of things that we had been doing in regards to a specific issue at the same time that the board was taking a look at the adjustments that we made relative to the NCAA. So we've been very involved since that time. We've been very engaged since that time. And, frankly, we've been extremely supportive of the work by the NCAA and by the work of the board of directors in their efforts. And so that's kind of a framework of where I was coming from.

JACK EVANS: Thank you. President McPhee, would you like to go next?

SIDNEY MCPHEE: Yes. Well, good morning. It certainly is a pleasure to be a part of this panel. My involvement with this NCAA reform-by the way, I should give a just brief background. I've served of president now of Middle Tennessee State University for 11 years. As I've told a number of colleagues, I'm living on borrowed time. Prior to that, I served in academic roles as associate provost at the University of Louisville, senior vice provost at the University of Memphis, and eight years in academic positions at Oklahoma State. In Tennessee I have served as the vice chancellor for the Tennessee Board of Regents, the sixth largest system of higher education in the country, over 200,000 students, and also served as chancellor of that system for a while and currently in my role of president of Middle Tennessee State University. By training I'm in the areas of counseling/psychology, and that has helped me in my role as an administrator at a major comprehensive university such as MTSU.

My involvement and role in academic reform date back to my first service as a member of the board of directors. I was serving with my colleague here, President Cartwright, during 2003 through 2007, and I'm actually on my second term, five-year term, started last year, my second five-year term as a board member, and also as a member of the executive committee.

Actually, it was quite interesting. I was one of the early advocates of the academic reform then as a board member. I was very much involved in pushing through the first set of reforms. With only the surprise after we voted for the APR to get back to my campus after the first report came out that showed that my football team had the lowest APR in the country. I was in my second year as the president. It made USA Today and many other news outlets, and I got calls from my board of regents members and of course a lot of my alums, and those were not pleasant calls. At that time no one told me as a president that you really should be spending a lot of time with intercollegiate athletics. And I had an AD at that time who thought that the president had no business dealing with athletics, and I didn't know any better, so I let him kind of run the place. But as a result of the APR, the initial report, I became very much involved in the internal operations of the campus with regards to the 
academic side of our student-athlete and our athletic program and began to work with the entire campus to develop what we called about eight years ago the Academic Game Plan that involved the provost's office, the student affairs office, athletics, and the president's office in changing the culture of athletics within the campus.

The long and short of that story is since 2003-2004, our APR score was 812 for a football team. Two years in implementing that Academic Game Plan we are now for the past five years have had a sustained improvement in the academic performance, not just of our football program, but our entire athletic program. Now we are ranked one of the top ten best academic performance athletic program in the NCAA Division I and have received-our football program actually received a top ten award just this past year from the NCAA.

Now, that called for some serious changes in the way we're doing business. We made changes in athletics personnel. And, by the way, I took the responsibility personally and said to the press that the buck stopped with the president's office. I didn't throw the blame out to others. I took the blame on and made some major changes. We got a new athletic director. We restructured our academic support center. We engaged the faculty, the faculty athletic rep. We put in an objective-based study hall. And there were a series of other changes implemented - the whole plan involves about nine components that has really resulted in some major, major changes in how we do business and how we operate the athletic program at the university.

My current role as a member of the board and member of the executive committee also involves serving as co-chair and now chair of the Student Well-Being Work Group that came out of the Presidential Retreat meeting in August of this year organized by President Mark Emmert. And I'm currently engaged in dealing with the proposal that's out there regarding the cost of attendance and have worked with my colleagues through that process. So through the years, the past eight years, I've been intimately engaged through the NCAA Board, on the executive committee, and as a president of a major campus that really is considered now the role model in terms of changing things around academically for student athletes.

JACK EVANS: Thank you. Chancellor Perlman, please.

HARVEY PERLMAN: Well, hello. I'm Harvey Perlman. I'm chancellor of the University of Nebraska - Lincoln. I'm in my 12th year as chancellor, if you count my interim period.

The reputation of the NCAA convinced me at the outset of becoming chancellor to avoid any involvement with it as long as I possibly could, and I managed successfully to do that until about four years ago, when I represented the Big 12 on the board of directors until we were no longer members of the Big 12. And my participation with the APR during the two-year period on the board was to listen to Walt Harrison do these long descriptions of all of the data that backed up all of the rules, and it was informative and skillfully done. I did attend the presidential retreat, where there was clearly a strong commitment to academic reform. In fact, I think most of the presidents who were there and most presidents I've interacted with believe that that is the signature program of the NCAA in our perception of how to go forward with intercollegiate athletics. I think it was taken implicitly as the right thing to do and the more you could do, the better. I now serve on the rules reform committee or working group, I guess, so that will explain the comments that I'll make in half a second. 
So I come from an institution that has more academic All-Americans than any other institution in the country. We've been proud of our commitment to academics in the athletic department. We're not perfect by any means, but we've had some success and we invest quite a bit of resources in it. And, frankly, until I got here today and listened to the presentation this morning, I didn't realize this was so controversial. It seemed to me it was a no-brainer. The more you can incent students to perform, they will. The more you can incent coaches to care about students' academic success, the more coaches will pay attention to it. And I am very much an incentive-driven person. So when I listen to some of the concerns that are expressed, and one has to acknowledge them, we should recognize that the more standards you impose or the higher standards you impose, the less perfect they will become. You will exclude some that should not be excluded. You will include some that should not be included. That seems inevitable in a system where standards are imposed.

I don't think the APR can solve the problems of the world. It will not solve the differences between differentially resourced institutions. It won't solve the problem of racial discrimination in the country. It will not solve the problem of students coming from different resource backgrounds and different classes. But it will-one has to, seems to me, ask the question are poor students better off with academic standards than without. And for me that's a pretty easy question to answer.

From the rules perspective, I do think, as I think about incentives and about coaches caring about success. I think the one consequence of the academic reform movement that's not been fully realized and hasn't been fully implemented is that in any serious student-athlete's life, the coach - and we've said this, we say it all the time-plays the central role in that student's experience at a university. They spend more time with them. It is a more intimate relationship than their relationship with their philosophy professor. It is an intense relationship. And it strikes me that what the academic reform movement has done is to try and create in that relationship an incentive for the coach to care about academic performance. And if that's true, then many of the rules that this organization currently has that are designed to ensure that the athlete is separate from the coach are counterproductive, in my view.

So why would we have a limited number of coaches? We couldn't say we want to have a limited number of biology professors. We wouldn't want to keep the student-faculty ratio as high as possible if we thought coaches were going to have a positive influence on this, and I think most of them would. Why do we have rules that limit the amount of time or the context in which coaches interact with their student-athletes? If a coach has as much incentive to make them academically successful as athletically successful because it impacts their ability to participate on the team or the team's ability to participate in contest, then maybe we shouldn't worry so much about the time and nature and context of that relationship. Maybe we ought to build on it. So I'm probably the devil incarnate in the room, and I'm also the newbie, and so I'm always open to listen to being convinced otherwise.

JACK EVANS: Thank you. Kevin?

KEVIN ANDERSON: Thank you, Jack. Good afternoon, everybody. Happy New Year. My name's Kevin Anderson. I'm the athletic director at the University of Maryland. I've been there about a year now. Before that I started off at Stanford 
University. I worked at the University of California, Berkeley; Oregon State; and I was the athletic director at the United States military academy at West Point. As athletic director at West Point, I didn't really deal with APR. I didn't have to worry about that. But going to Maryland, there were situations where I did have to pay closer attention.

I first became involved with academic reform when Myles Brand asked me to be on the Basketball Academic Enhancement Group. And there is where my eyes were opened to serious issues that we have, particularly with men's basketball and young men graduating. The group was made up of presidents, FARs, athletic directors, people from the NCAA, and there was very good and enlightened conversation. I think we didn't know what to expect once we walked in the room, but walking out I believe that everybody was educated and understood the complexity of what we're dealing with now, particularly with these young men. There was a bunch of statistics shared in the very beginning, and one of the statistics that was alarming is that there was a box of young men that we were very concerned about. It was about 45 percent of the population that makes up men's basketball. And out of that 45 percent, most of them were young men of color. So we needed to talk about what do we do to get them to be productive and to move forward to graduation.

And I believe that we probably came up with two ways to look at it. One way is that we have to make an initial investment. We have to do more assessment of where they are coming in, and then we have to provide resources to have them move through the institution. Or we just look at it and very simply say that they're not prepared to come and tell them that you will not be welcome to our institutions.

So some very good work came out of that, and we came up with a plan that we thought would be productive in having them work towards graduation and being a productive part of their institutions. As Dr. Harrison said this morning, that some of this or most of it has been bogged down in committee and it hasn't moved forward yet. The thing that was disappointing I think in the committee work is that it became, as most things do, and I am political science, it became very political.

We talked about amount of hours that we would expect a young man to come in beginning in the summer of his freshman year, and we fought about that because some of the coaches were concerned that if it was six hours and they failed to get six hours or three hours that they'd be ineligible. There were things like that that were put on a table where the concerning part is that in trying to improve what they're doing academically would be questioned, and that failure would not be parted if we did our jobs. So we're hoping that this legislation and this work in the committee will start to regain movement. I believe if it does, it will help particularly in men's basketball.

JACK EVANS: Thank you, Kevin, and thank you, each of you. That completes a first round of discussions in which you've heard from each member of the panel. Let me propose some ground rules for going forward. One of those is to assure people in the audience that I intend to protect some time in which you all can ask questions to be addressed by members of the panel.

The other ground rule that I will suggest is that as we now move into some other questions, let's agree that not everybody on the panel has to speak to every question. But if you want to add something to what has already been said, you're welcome to do it. The next question that I want to pose is one that has already been 
addressed to some degree by some of the members on the panel. That question is, "What happened regarding academic reform at your specific institution in the early or earliest stages of this round of academic reform? Are there any particular things that come to mind?" Mike, you already addressed that very specifically, and, President McPhee, you've done the same. Let's just see if anybody would like to add to that part of the dialogue about the early chapters of academic reform.

CAROL CARTWRIGHT: Jack, if I could just make a general comment, and it gets to presidential leadership, which is a part of all of these discussions in the colloquium. It seems to me that if presidents were engaged in the issues and understood that reform was coming, and they would certainly know that if they participated in conference-level discussions about reform, there should not have been significant impact at an institution because there was time to get ready. I would worry if institutions were surprised or caught off guard. I take Sidney's point about understanding that a lot was already in the pipeline. It could have an impact when you had the first knowledge of it. You would then immediately set to work to deal with it. But just in terms of the general aspects about the reform packages, people should have seen them coming, had they been engaged, (as I think presidents should have been) in these discussions.

JACK EVANS: I think you make a point that the new-the standards, the new measurements, the new consequences - this may have been one case where the relatively long legislative pipeline of the NCAA served us well, in that, as you say, nobody should have been caught by surprise. But, President McPhee, you made the point that when all of this hit and you looked at the specific results at your institution, you saw some things that had not previously been on your agenda. And if you'd like to add to that, please do.

SIDNEY MCPHEE: Yes. And the whole issue has to do with the communication and being involved to the extent that you're not micromanaging as a president but that you're informed. And, quite frankly, I was uninformed. And I blamed myself for not being informed. Because I'm informed what's going on in the academic side of the university and met regularly with deans and the provost and chairs. So I use that model, and I've used it ever since with athletics. And so my AD serves on the president's cabinet and I'm fully engaged.

There's one point I want to add that there's been a great deal of discussion on the board with regards to the impact of these reform issues, particularly the APR and the issue of resources. Chancellor Perlman mentioned earlier about the lower-resource institutions and some of the impact. Some folks believe there's a school of thought that our institution's resource level should not be taken in consideration. I'm one who feels that an institution's resource level should be taken into consideration. Now, money doesn't solve every problem. But certainly if you don't have the resources to provide the support, like we do for any other student on a campus, for your student-athletes, you're not going to see the kind of results.

So at MTSU we made some cultural, structural changes in terms of impact that involve some personnel. As I mentioned to you, we ended up getting a new coach, a new athletic director. We put a significant amount of dollars in our student-athlete 
enhancement center, and fortunately as an institution we're able to afford to do that. But on top of that I use this term, not only with our academics, but also with the athletic folks: ROI, return on the investment. And for athletics, as with other parts of the university, it's the results, the outcomes, the performances of our students. And so as we added additional resources and provided support, we have some very specific goals each year. And at the appropriate time I'll be happy to share with you. We are very, very proud of the sustained results we've had the past five years.

JACK EVANS: Thank you. Would anybody like to add? Please.

HARVEY PERLMAN: I can't do an empirical comparison, because I wasn't paying attention before, but judging from some of the whining of some of our head coaches who are not whining about academic reform, but whining about the things that impact that reform at the margin, the concern about the transfer rules and the concern about some of these other things, suggest to me that they're paying attention to it, which is a good thing.

And I also sense that there is a different relationship between the coaching staffs and the academic support units. I mean, I think that relationship at our institution was always pretty good, but I think the coaches see them as becoming almost as important as the weight staff, right, the conditioning staff, because both of those will determine the success of their teams, and that's I think what the reform has done.

KEVIN ANDERSON: Harvey, I agree with you. And I think that now when you're looking at hiring coaches and ones that you have on your staff, that this has to be a constant conversation. And when you sit down and you talk about staffing, wins and losses and everything else, that you have to look at the APR and grade point averages and all that. And if it's not part of the conversation, then you're going to head down that road where you will have issues. And I think that most coaches understand now that it's very important that recruiting the kind of young people that they know we bring in and they need help, that they will put forth the effort to be successful both in the classroom and on the field because of the changing climate.

JACK EVANS: Thank you. I'm about to do something that a panel moderator probably should not do, but I'm going to sandbag these people with a question that I didn't include on my advanced list, but it goes this way. As I listened to yesterday's sessions in the colloquium and the session this morning, I heard a lot more discussion of issues than I did about the topic of leadership. But until we got to Secretary Duncan's talk where he actually spent a good bit of time on that theme, and President Cartwright raised it, the dialogue during the colloquium hadn't really addressed the topic of leadership as part of academic reform. And I would just like to tee that question up for the panel to talk about, because you're looking at a panel of leaders at their respective institutions and in their roles as professional educators. The reason these people were chosen was because they have done things as leaders related to academic reform. I invite any member on the panel to pick up on that one, if you would like to.

CAROL CARTWRIGHT: Well, I don't think that's sandbagging at all. I think that's an absolutely terrific question, because at the end of the day, it is all about 
leadership. I would quickly add that I believe that leadership is diffused throughout an organization; that everyone, whatever their responsibilities, has in their sphere of influence an opportunity to provide leadership. It's the president's responsibility to set the tone at the top, to be clear about expectations, but also to create an environment where people know that if they step up and be a leader, they'll be valued. It is just a sense of permission to be a leader, but almost an obligation to get involved in the life of the institution. This is an expectation that you do what you can wherever you are to advance the mission of the institution, including the mission and role of intercollegiate athletics.

I have had ADs as a member of the president's cabinet, not because I want athletics represented at the table, I do, but because they are leaders throughout the institution. They bring their problem solving and communication and analytical skills to the table, and they're ambassadors for university-wide issues and opportunities wherever they go in their sphere of influence. Of course, there's also the value of having their issues addressed at that level.

I don't think there's anything more important than leadership. Without it, you really can't get anything else accomplished. Ron Smith told me yesterday afternoon that I was not going to like what he said about presidents. And he's right. Because in several ways he implied that presidents could not get the job done. I would submit that presidents cannot get the job done by themselves. But if they are not engaged and not setting the tone and not getting the right people involved, then it won't get done at all.

JACK EVANS: Would anyone like to add? All right. Then we'll move on. Let's go to a somewhat more focused question, and this is one on which Chancellor Perlman touched. Let's talk about how your coaches have responded to implementation of the various dimensions of academic reform, the metrics, the standards, the consequences, et cetera. Would anyone like to open on that one?

KEVIN ANDERSON: Yes, I could speak to my organization. I believe that, again, talking about leadership, if the tone is set at the top, I believe that they will respond. And I've seen that. We talk about this all the time, and that they know it's very important to me. They know it's important to our institution and our president, and so it's important to them. And we're doing things to make sure that we are not only compliant, but we're doing above and beyond what our expectations are.

MIKE ALDEN: I think, Jack, and with coaches at least, and we're all like this, is that, you know, everybody wants responsibility. They all want recognition. They all want to be empowered to do their jobs. But I think that when you all of a sudden hit that fourth one, which is you're going to hold people accountable for that as well, too, that becomes...sometimes can be challenging for people if in fact they don't see themselves in those type of leadership roles. They want to see it. They want the recognition. They want to be empowered. And they certainly want the responsibility But coaches and staff members, or I think all of us, are like that. But then when you start taking a look at the accountability factor, that's where the leadership part that President Cartwright was talking about, I think really has to be able to be transferred. And I think by bringing everybody together, talking to them about what we're trying to do, equating it to no different 
than asking a running back to doing a certain type of thing and they're going to be accountable if they fumble the ball or, you know, a softball player to do these things, and that coaches, I do believe, as Kevin was saying, are going to respond in a positive fashion. And that accountability isn't just about winning the game. That accountability is how are your kids doing off the field. How are they doing in the community? How are they doing from an APR or graduation standpoint? And so I think the resistance initially is you feel the accountability because you feel pressure. But I think when, from a leadership standpoint, when you see everyone together, understanding we're all going to be accountable for these things, then I think you're going to see people step up and they respond to it. And at least for us at Mizzou, they responded in a positive way.

JACK EVANS: President McPhee, would you like to add something?

SIDNEY MCPHEE: Let me take that from a different perspective. The coaches are responding well on my campus, and I'm a little bit cynical about that because, like many of our campuses, we've built in now the APR and performances of the APR in their contracts, and they receive big checks. I'm not sure that's the right way to go. We're going down that road we have, but, you know, do we give faculty members financial incentives for the performances of students in their classes? And I look at some of these bonuses, and, again, it's the reality we have to play that game. But for us it is a major part of our discussions with coaches. Coaches who do not response positively to their student athletes' academic performance do not survive in their positions at our university. But I've got to think and worry about how much that incentive, financial piece, is a part of what we do.

HARVEY PERLMAN: I sense there is, at least with the coaches I've talked to, there is a changing view, that we're at a tipping point; that as the criteria become more stringent, I think we'll move them to the right place. You know, before they were talking - at least the conversations that elevate to me, which are not all the conversations, I know-were about, well, you know, how can we do this with the transfer standards and how can we do this with this and these are the problems. The most recent conversations that I've had were we really have to do something about letting high school guidance counselors know what the rules are. One coach said to me: You can't believe how many mothers look at me and say, "You mean if they just graduate that isn't enough to play?"

So they're starting to think about what, the organization can do to, in a sense, implement this system. They're concerned about the proposals to limit the number of sports-specific non-coaching staff. With the coaches focused on coaching during the season, the other staff are the folks that are trying to monitor the academic performance of student-athletes and making sure that they're going to class and all the other kinds of things that have traditionally been done. So I think at least the conversations I've had have changed from the, you know, change the rules so that I don't have to work so hard to what can we do to make the system better. That would be a good movement, in my view.

JACK EVANS: Let me pose a complementary question to the panel and ask if you have found innovative roles for faculty, either the faculty athletics representative, 
your faculty senate, your faculty athletics committee or council or whatever it might be called at your particular institute. Would any of you like to talk about that? And, President McPhee, I saw you nod your head, so let me pick on you first.

SIDNEY MCPHEE: Yes, because in that I mentioned our Academic Game Plan. We actually elevated, enhanced the role of our Faculty Athletics Representative (FAR), and he actually is - I call him the de facto president in his role in representing me on athletic matters. He speaks for me. He's empowered by my office. The coaches know it. He has a direct line, direct connection to my office, not through the athletic director's office, and that has really worked.

Interestingly, just before I came to this convention, he informed me that our APR scores are fantastic. We conduct a complete analysis of every single grade, every athlete on our campus each semester, and this past semester he saw a trend that he didn't like. And he visited my office last week to make me aware of that, and, as a result, we have a meeting coming up next week with the AD, the VP for student affairs, and the head of our academic enhancement center in my office next to deal with that issue. So he plays a very important role. They know he's just not there to go on free rides to football and basketball games and buddy up with the coaches; that he really is the eyes and ears of the president.

JACK EVANS: Anyone else?

CAROL CARTWRIGHT: Jack, I don't think this is particularly innovative, but we exist in a larger environment, and the calls for accountability on many fronts have significantly increased in the last couple of decades. I think more schoolsI certainly know this is true in the Mid-America Conference-but I think more schools have been much more transparent about data, including budget data and academic performance data in intercollegiate athletics and have been quite excited about getting faculty engaged in various ways when data are being reviewed. Again, this is not innovative, but I think it is a good move overall to get people engaged and looking at the issues both financially and academically.

JACK EVANS: Any specific good practices that you'd like to identify?

CAROL CARTWRIGHT: Well, again, we fund intercollegiate athletics through a student fee. That's been historic in the Mid-American Conference for more than 50 years. There are no secrets about it. It's always been out there that this is the way we fund programs, and that's also the way we fund a student recreation center and student health and a student union and all kinds of other things. We account for the percentage of that overall general fee that goes to athletics and what goes to everything else.

I have never used a presidential override on a special admit. We have a faculty committee. Theoretically, the president would be the arbiter if there were a major debate. But in 20 years, I never had a case brought to me. What the faculty said was what happened. These are just basic good practices — not anything that's necessarily wildly creative or innovative, but good practices.

JACK EVANS: But not necessarily uniformly deployed across the membership? 
CAROL CARTWRIGHT: I know it to be true in the MAC. I can't speak for others. And conferences do have different cultures about the extent to which presidents are engaged at the conference level in the sharing of best practices. Some conferences have now implemented a process whereby provosts meet regularly. That might be regarded at somewhat innovative, and I think that could be very helpful as well.

MIKE ALDEN: I'll just give you four specific things that we've done on our campus over the course of since we implemented APR. One is, and many of you do this, we have a guest coaches program which we invite our faculty staff. And so we'll touch about 50 faculty staff members per year. And we've done this now for nine years. So, you do the math. I mean, that's roughly around 450 people. And that could be anywhere from a full professor in the College of Business to perhaps an assistant registrar. So we're going to cross the gamut of that. And what that's allowed us to do is certainly allow our faculty and some of our key staff throughout the university to be able to really see what we do on daily basis, what we're trying to do performing to be able to support from an academic performance standpoint.

The second thing we do is we have faculty staff luncheons. We have six of those a year where we invite in our faculty staff to come in for a luncheon. It's like $\$ 5$ or $\$ 10$, something like that. And so we'll have faculty and staff that will come in, primarily faculty that will come in, hear from our coaches, hear from our academic advisors, just get an update on different things that are happening within intercollegiate athletics. That's become very popular for us.

A third, which was challenging for me to do the very first time, because I invited myself along with the faculty rep. No, I didn't invite the faculty rep, because that's one of my bosses, but we invited ourselves to a faculty senate. And we go twice a year to the faculty senate. There's four of us who go- our faculty athletic representative, myself, and a couple of others - and spend some time with our faculty senate, talk about where we are on the APR, talk about what's happening with our budget, the transparency that Carol was talking about. I mean, we give them everything out there, all the good and the bad.

And then, finally, we also have an annual coffee with the chair of our faculty council as well as the vice chair, myself, faculty rep, and a few other people will get together before the year.

So those four things for us, Jack, over the course now of nine years we've been doing it, really we've been able to touch a lot of people. We've been able to really, from an educational standpoint, educate ourselves on what our faculty are looking for as well as try to educate our faculty and some key staff members on where we're at right now and trying to perform well academically, financially, whatever it may be, in athletics, but those are four specific things that we do.

HARVEY PERLMAN: Well, with my faculty athletic rep in the audience, I have to say something. No, seriously. I, like Sidney, do think the idea of presidential control is great in the abstract, but in fact it's the faculty athletic rep or somebody, whoever you pick, that exercises day to day involvement for the president. I'm not going to deal with the day-to-day activities in the athletic department, and you do need somebody there as a president that you have full confidence in to be your eyes and ears and your voice. And I have that. 
What we ought to be realistic about with elevating academic standards is that you will elevate the incidence of fraud. I mean, that's inevitable. You have to have a realistic view about human nature. And so the role of the FAR I think is going to be increased and looking at activities that would suggest that there's ways to game the academic reform effort.

Some of the "gaming activities" are legitimate; not legitimate, maybe, but some of them at least have adverse consequences. There was a lot of conversation this morning about athletes clustering in certain kinds of courses. Now, I know we review all of the athletic student-athlete transcripts to look to see if there's clustering. As a president, I look at it as kind of the canary in the coalmine. If student-athletes are clustering in a particular academic program, then I have more issues with the academic program than I do with the student-athletes. And my guess is if you took transcripts of fraternity guys, you'll see some clustering there too. So, I mean, I think we have to be realistic about this.

But, you know, incentives work, and coaches work in good faith, but none of these issues are factually easy. And the incentives for a coach is always to give the benefit of the doubt to the student-athlete, and I think realistically you need somebody to look at it that's more objective or at least more vigorous in terms of some of these things that-you know, the magic semester of 30 hours in two weeks to get the grade point average up to 2.5. We'll have more of that. And I think you need to be careful.

KEVIN ANDERSON: I think Chancellor Perlman brings up another important fact. Now that we're looking at raising the GPA from 2.0 to 2.3 and we look at the high schools, many of these counselors and teachers will help our student-athletes raise to that level because they believe that if they allow them to do that, then it's helping them better their lives. So now we've got another issue because we're already looking at young people that aren't prepared. And so now with raising that bar, we're going to see that there could be folks not ill intended, but they will look at how can I help this young man or young woman go to a university, an institution, to better themselves. And so that's another can of worms that I think will be opened and that we have to look at.

JACK EVANS: Thank you. And, Kevin, you just touched on the fact that standards have been raised. A new set of penalty thresholds is in place. That's a body of work that's been done by the Academic Cabinet and the Committee on Academic Performance and subsequently approved for implementation by the board of directors. With that background, I'd like to ask members of the panel a question that goes: If you had an opportunity now to convey a message to either members of the Committee on Academic Performance or to the Board of Directors on the subject of academic reform, what would you like that message to be?

CAROL CARTWRIGHT: I'll kick it off. First of all, I applaud Walt Harrison for his leadership on the Committee on Academic Performance, particularly in his willingness to stay with it. I think the stability of leadership matters. The sense of being deeply informed over the years matters. And it seems to me that the proposals that they have been sending forward are in the best spirit of continuous improvement, looking at what has worked, being willing to consider new evidence, and look at how to make revisions to constantly make improvements. 
That said, I also want to reinforce what Harvey Perlman said about the role of incentives. I would urge support of proposals that have come from the Knight Commission (and were acknowledged by Secretary Duncan) about tying more of the financial gains to academic achievement, from the basketball tournament and the bowl revenues, for example.

SIDNEY MCPHEE: Yes. I certainly would suggest that we continue the reform movement, but-and I think the NCAA has shown the ability to be aware and to respond to unintended consequences. And some of the changes and the tweaking in the initial academic reform really shows that there are unintended consequences -and I'm certainly dealing with it now on the Student Well-Being Workgroup, to make sure that we get all the voices at the table; that where these changes would have the impact on it and get feedback, but also be flexible enough to make adjustments when the unintended consequences become evident.

KEVIN ANDERSON: What I've seen with our coaches is that they've embraced it. They've questioned it, but they've embraced it and they've taken it on with great pride because they're teachers. They know they're teachers, and part of the experience is not only doing well on the field, but in the classroom. And I know that the group of coaches I work with have really moved forward with this and want success and take pride in how-what is reported in the classroom and how well their student-athletes are achieving.

JACK EVANS: With that, I observed that we're beginning to lose a few members of the audience, and I don't want to do that before giving those of you who are interested an opportunity to ask questions of the panel. So let's open this discussion up to members of the audience. We have microphones that are posted down the middle aisle. So if you have a question, I'd be grateful if you would come to one of the microphones.

DERITA RATCLIFFE: Good afternoon. Derita Ratcliffe, senior associate athletic director at UAB. My question is to essentially Dr. Cartwright, but anyone else who would like to chime in. You made mention of Secretary Duncan's comments about moving proposals through versus your comment earlier about how long the process was in implementing APR, which I think was critical to its success. How do we, going forward, manage those two, moving things forward in a timely manner, but also giving institutions time to adjust? With differences in resources, some schools may take longer to adjust to a given change in academic package than others.

CAROL CARTWRIGHT: I think what drove the early discussions about timing really had to do with a very strong rationale for when you start the clock ticking and how long it takes to show improvement. If that rationale doesn't hold up, then things can be moved more quickly. There was a reason for allowing people to move toward the reforms over time. For example, it was important to acknowledge the time it takes to get through high school. So that's why that was done that way. It wasn't to try to make it easy for people to phase in or try to allow them an opportunity to garner the resources that they needed to do it. It was simply the realities of how students move through school. 
BOB CHICHESTER: Thank you, Jack. My name's Bob Chichester, and I'm actually a member of the NCAA staff. I've been fortunate to work on the Academic Performance Program as well with FARA in my time in the National office. And my question is for the presidents and Chancellor Perlman. And because athletics is sort of a microcosm of what many of us do, it's a broader-based educational question, and that is given that overall the graduation rates of student-athletes has tended to exceed the graduation rate of the student bodies in general and that we certainly know we have crises in higher education around the country, and that we have a number of membership schools whose graduation rates of their general student body is less than 50 percent, my question really is I'm curious from the presidents and chancellors about the propriety or the lack of propriety of evaluating academic departments and faculty members based on the graduation rates of their students within their departments.

HARVEY PERLMAN: Actually, we're going to start doing that. We've set out some fairly significant goals for us as an institution in terms of retention and graduation rates, both time to degree as well as degree itself. And we are in the process of thinking through what sets of incentives one could provide to academic units to incent them to increase those rates for all students. So I don't have any problem with that.

It is true. I mean, I think one of the helpful things for me when I look at some of these regulations, some of the arguments against intercollegiate athletics is to compare what we do with student-athletes with what we do with students generally and to test to see whether they're close enough. Now, we spent a lot more money on student-athletes to be sure.

CAROL CARTWRIGHT: I would like to see the GSR replace the federal metric. We're saddled with a metric: full-time first-time freshman who stay at the same institution to complete a degree, as our measure of a graduation rate in this nation. That's a '60s metric. People do not go to school like that anymore. We make it easy for them to transfer-they change majors, they fall in love, they fall out of love, they want to pursue something and drop out for a while. And we don't count those students. The vast majority of them eventually graduate somewhere, but we don't track that. So we really don't have a good measure of the general student body graduation rate over time because of their comings and goings as we do of student-athletes. I would like to see us use the GSR as the model for how we measure graduation rates in this country.

SIDNEY MCPHEE: And the Tennessee General Assembly has actually mandated a year ago through the Higher Education Reform Act that all Tennessee universities are now actually are funded based on retention and graduation rate outcomes rather than enrollment. And on my campus this past year we had discussions about publishing the graduation rates by colleges and departments. And you should be a fly on the wall when I announced that in the faculty and general administration meeting to hear the feedback on that. But we're actually moving in that direction as we speak. And as you can tell, when you compare graduation rates of the general student population with the student-athlete, the numbers don't look good. 
JACK EVANS: Anyone further? Scott?

SCOTT KRETCHMAR: Scott Kretchmar, Penn State University. I have a question about a possible missing piece in academic reform. And I think it refers to the relationship between the coach and the athlete that was mentioned earlier. And I've been impressed by the data that show the coach being a significant other in the lives of our athletes. And I think that that's important data and I think we should take advantage of it. What I worry about is that the kinds of realistic pressures that exist for coaches today make that kind of trusting relationship a difficult one to generate and to keep in place. Coaches who we know need to have players who can win, and if a player doesn't pan out or doesn't mature or play as well as the coach thought when they were recruiting becomes a liability on the team with regard to what coaches care about a lot, which is making sure they have winning programs.

So this gets to Mr. Perlman's comment there about this relationship and mixed messages that we send to students, where ideally a coach now has more incentive to say I really do care about your academic progress. But then, on the other hand, the coach has an inordinate amount of power over that player, that says out of the other side of his or her mouth, in effect, if you don't mature and play as well as I thought you would when I recruited you out of high school as a junior, you're not going to have your athletic scholarship anymore. Good luck to you. Good-bye.

And I'm disappointed personally that the four-year scholarship has not gotten more traction. I know there are all kinds of have and have-not equity issues with this. But to make this relationship work, it seems to me that that's an important piece of the puzzle. I'd like to hear any reactions to that.

SIDNEY MCPHEE: Well, since that's in the committee that I' $m$ chairing, would you like to do an advertisement for the multi-year scholarship proposal? I had the opportunity just this past week to read every single comment on the override on the four-years scholarship proposal, and some of it really amazed me, to read some of the opposition to the proposal. The proposal is more symbolic. If I'm giving a push for that, forgive me; I'm shamelessly doing that. Because I do think that it shows a commitment on the part of the institution to the well-being of the student athlete. And we had a number - we had at least one coach on that committee that made the same point that you've made. So certainly I'm supportive of that multiyear grant. The main issue of course was cost. But it's hard to argue against that.

KEVINANDERSON: Yeah. I believe another concern is early commitments. We have student-athletes coming and committing without even coming to campus. I think that there're issues that we're not able to analyze what kind of student they're going to be, and so I think that's another issue that we need to talk about, because it creates all kind of different issues for us. So I think that goes hand in hand.

MIKE ALDEN: You know, and Scott, there's other things too that-you know, the men's basketball new recruiting model that we're seeing right now, some of the intentions of that were to allow relationships to be built, what Kevin is talking about, those early commits, build those relationships sooner, get those kids and their parents or guardians to campus sooner, do all those different types of things here building relationships. But in listening to also some of your comments, I 
think if we find ourselves having coaches that feel the pressure to win and pressure to play a player, well, then maybe some of us, like me, right, and our roles and maybe people like right here in her roles, maybe we're not doing a really good job in leadership roles with our coaches. Because I think if we define and see that, and Sidney talked about culture, if we're seeing that as part of our culture on our campus, then I better look at myself in the mirror, because then I'm not doing a really good job in a leadership capacity with our coaches.

And certainly we do see that out there. There's no question it's out there and that you're going to hear those types of stories about coaches, the one-and-dones or pushing them out themselves or whatever's going on. But I would tell you, again, the point that you talked about, and I listened very clearly to what you were saying, I think if we see those happening on our-that's our responsibility, not our coach. That's our responsibility, and we need to look ourselves in the mirror, say what kind of leaders are we being if in fact we're seeing those things take place on our campuses.

UNIDENTIFIED SPEAKER: Hi. I'm sympathetic to what you say and sympathetic to the mold of your scholarship, but I don't think it's as easy as that either. You know, as I said before, I compare it over to the academic side of the institution. We give scholarships, but they're all conditioned on performance.

I mean, if you don't get a certain grade point average, you'll lose it. Some of the comments that we've heard are crazy about I changed offense and so this person doesn't fit anymore. But there is also the student-athlete that just doesn't care, gets there, decides not to, and how there's got to be a-I think additional thought has to be to that issue. But you're absolutely right.

SIDNEY MCPHEE: I do need to add the committee really talked through and discussed the issue of whether or not it doesn't work out and it's mutual. And within that proposal, there are opportunities to make that adjustment. And so this is not a locked in, but just like any other academic scholarship, if you look at the commitment for academic scholarships, unless they're not making the grades, it's a four-year deal. And so we're really trying to make it very close to that and take out the factor of he's not performing, she's not performing, or you have changes of coaches and therefore you're going to go in a new direction.

JACK EVANS: Next question, please.

FRANK SMITH: Thank you. Thank you. Frank Smith. I just joined the NCAA as assistant director of enforcement. But my background is as assistant basketball coach on the college level. So I wanted to allude to, Mr. Perlman, you mentioned earlier limiting the contact with the coaches and student-athletes. Can you talk about any proposal or any talk or mentioning of giving the coaches more contact in the summertime, which may help with the APR?

HARVEY PERLMAN: I believe there is a set of proposals that actually were adopted by the board relative to basketball that does provide some summer interactions between coaches and players. The question will come up as the working group on the rules looks through the rules and asks the questions which of these rules should be retained and which shouldn't be on a more general basis than just basketball. 
MIKE ALDEN: So, Frank, again, to what Chancellor Perlman was saying, that's going into place this coming summer for basketball. So the leadership council put all that together. And it's really cool. In their junior year, you're going to start that unlimited contact with those kids, you know, right away. And then of course in the summer you're going to have a chance to have contact, you're going to bring them onto campus. And so that model that we've proposed and the board has approved, right Sidney?

SIDNEY MCPHEE: That's correct.

MIKE ALDEN: Okay. This is going to be something that we'll be monitoring now how do we implement this in women's basketball, how are we going to be doing this in other sports as well too. But I really think it's a pretty neat model that's going to provide that type of contact so those relationships can be built before they get to campus.

FRANK SMITH: No, I'm referring more to student-athletes that are already on your campus, your current players.

MIKE ALDEN: Well, that's still-that's something actually we discussed, if I may, with the board at our most recent board meeting, which I think was a few months ago, and we'll be discussing that again this week, and that has to do with the contact in the-primarily in the summertime, allowing us to be able to work with our current student-athletes more in the summertime. Yes. And so that's going to be discussed this week.

FRANK SMITH: Thanks.

MIKE ORIARD: I'm Mike Oriard from Oregon State University. This is for Presidents McPhee and Cartwright; the fact that you're from have-not universities in relation to BCS schools and so on. And, President McPhee, you mentioned, more or less in passing, that you acknowledge the differential impact for low-revenue, high-revenue teams. You had the resources to put into improving your academic support. But those resources were not just available to you. They came from somewhere else, so you had to make a strategic decision to put institutional resources towards athletics. And the justification is the return on investment. And I'd like you to elaborate on that, if you would, and I'd be interested if President Cartwright has any comments too.

It's been a while since I looked at this, but I recall the MAC schools have some of the lowest revenues in the FBS, and I think that at least several schools have some of the highest GSRs in the FBS, but you still have these resource issues. You said your programs are funded through student fees. If you needed to invest in academic support, and it's student fees, then you got to have more student fees or student fees going to athletics rather than any of any of the other places they go. I mean, I've wondered for a long time how you all survive and what kind of decision-making you go through to justify the investment of institutional resources towards athletics.

JACK EVANS: I think I heard two questions for two people. Should I flip a coin to decide who... 
CAROL CARTWRIGHT: Oh, no, we want to answer both.

JACK EVANS: Who defends and who kicks off?

CAROL CARTWRIGHT: Well, regarding the MAC, I think the story there is a firm commitment to being who we are. We understand the types of programs that work for us and the kinds of resources that are available to us. And we are willing to say "No." We know that very successful coaches will be recruited away from us. We're thrilled with the commitments and the achievements that they make when they are with us. But we're not going to match multi-million dollar packages when other schools try to recruit them. We just hope they remember us in their planned giving going forward.

We treat the athletics programs the same way we treat other programs. The AD needs, just as a dean would need, to set priorities within the allocated budget dollars. We've been rigorous about maintaining the same levels of increases between general university budgets and athletics budgets. We have not let the athletic budget move percentage-wise beyond the kinds of percentage increases that we have in place for the overall institutional budget. And that's what leaders have to do when they have programmatic and budget authority. They have to make hard choices. They've done that.

At Kent State, we had several major gifts from alumni that helped us create additional facilities and technology for student-athletes and an academic support office. And that was a very appealing fundraising priority for a group of alumni. But I think the key here is being who you are. The MAC presidents talk about this on a regular basis, about our value structure and our mission. And we're very proud of the fact that we do a lot more with a relatively small set of resources.

SIDNEY MCPHEE: Yeah, and just to add to that, no one said it's easy. As presidents we make tough decisions all the time. And, you know, I personally feel, whether it's student-athletes or just a regular student, that we have a responsibility once we admit a student, an ethical and moral responsibility to do everything possible to help that student be successful, athlete or non-athlete.

And so we just happen to be a very growing campus. We have a campus of approaching 27,000 students. We've managed our resources well even in these tough times last year. We had to cut $\$ 33$ million from my budget last year. That's State appropriation budget. But we've made tough choices. We've made some strategic decisions. And we approach our activities at our university as positioning the university for the future and we identify these top priorities with regards to graduation, retention, support, and the quality of academic programs. We are fortunate that we were able to add resources to our departments despite budget reductions. I know of other campuses where that might be a little bit more difficult.

So as a member of the board, I have been very much one of those persons advocating that as we implement these reforms that we take a serious look-and, Harvey, I think you were at one of our earlier meetings which I made - and at the presidential retreat, I made the comment-I looked around the table, and I said: Look who's around this table. Look-how many HBCUs are represented? Now, that comment dropped like a hot potato. And the comment I made was that as we implement these changes, let's make sure that we don't forget that there are others who are not in the same position that we are in. 
And there were some of my colleagues who had just signed some big TV contracts and they were pumping their chests about all the money that they had available. I remember that very clearly. Not all of us are in that position. And so we have pushed - and I know Walt Harrison has really been supportive of this, of looking at finding ways through the NCAA to provide support to those lower-resource institutions. We had a number of discussions of that at the board and executive committee to help those institutions in that regard.

MIKE ORIARD: President McPhee, could you talk about the return on investment from this strategic initiative in athletics?

SIDNEY MCPHEE: Yes.

MIKE ORIARD: How you perceive that?

SIDNEY MCPHEE: And it's not just athletics. And that is a concept we use throughout the university. For an example, for each new initiative, we have some very clear outcomes and objectives. If it's, for an example, in sponsored research, I've enhanced that office. We are bringing in X year. We're expecting some specific measurable outcomes associated with the investment of resources. We have set goals, specific goals, over a period of time of what that increase would be.

And, you know, I don't get support all the time from the faculty, because they see it too much as a business model. And over the past 10 years, I've had the opportunity to serve a number of bank and corporate boards, and we use a lot of that models, particularly in the banking industry with regards to the daily operation of assigning resources and then making sure that there's that return with specific goals, objectives, and outcomes. And we make it relevant to the particular program. You, you can't use the same outcomes for your music school as you use for athletics. But there are two areas at the university where it is very easy to measure outcomes. I always tell my AD and my vice president for development: At the end of the year, we can easily determine success. I'm opening myself for criticism, but I make the point. You can always determine success, either you are raising money or you are not. For coaches, you're winning and students are doing well in the classroom, or you're not. Now, you know, the faculty in English can say, yeah, we're doing great things. It's much more difficult in other areas. But those two areas you certainly can tie those outcomes to specific objectives.

JACK EVANS: Sir, I'll give you the distinction of posing the last question.

CARLYLE CARTER: That's great. And lunch isn't the next thing, so I should be able to handle this. My name is Carlyle Carter. I'm with the California Community College Athletic Association. And I have two of my colleague professors immediately to my right. And I will let you know that Ron Smith has mellowed over the years since my undergraduate days.

I' $m$ in front of you today asking for your support of the concept of an academic year in readiness. I think at the four-year level you're calling it an academic redshirt. At the two-year level, and I remember being a member of the-I'm still a member of the two-year relations panel-in 2007 we brought remediation to the agenda, and Dr. Brand at that time came into the meeting and we had a very forthright 
discussion on the need for an opportunity to remediate. And he turned to David Berst, and Beth DeBauche was there at the time, and said: Let's figure out a way to make this work. Here we are in 2012, and we have worked and we've been lucky enough to work with CAP as well as the academic cabinet in trying to work with some of the academic reform and its effect on the two-year-college student-athlete.

How many in the room are first-time college graduates in their family? So you know what the impact is on your families and the future generations.

We have 2.7 million people that attend our colleges in California every year at the community college level. Over 30 percent are Latino, Hispanic. Many, many of our students that are enrolled in college and are there are motivated by being there for an opportunity to participate in sport. Many have a dream to move to the next level.

We all know that our public education is failing in terms of providing proficiency in basic skills. We do a tremendous amount of remediation.

And if you are familiar with the 40-60-80 rule relative to transfers, as soon as this student is full time-and our students need to be full time for financial aid purposes, they need to be full time in order to remain on their parents' insuranceas soon as they're full time, and many of them are taking more than one unit of remediation, their five-year clock starts. They're required to get a certain number of classes or unit toward that 40,60 , or 80 . Those lucky enough to get there are left without a choice. And many who arrive on your campuses are put into a major strictly because they meet the 40, 60, or 80 in that major. They have no choice.

What we're asking for, and what we hope to get, is an opportunity for those students who are non-qualifiers to spend an additional year at our colleges off of the clock, full time, so that they can have a chance to improve their basic skills, so that they have a chance to be successful when they do transfer. We understand the 2.5 , the additional science course, all of the reforms that are going to be in place. But we really need the opportunity to work with these students so that they have a chance at the next level. Thank you.

JACK EVANS: I think the central question was about what's been called the academic year in residence, particularly at the two-year college level, and I think Kevin touched on the fact that that topic emerged initially from the work of the Basketball Academic Enhancement Group with which we were both involved. Would anybody like to speak to that?

KEVIN ANDERSON: Yeah. I truly believe your point, and I think that we have to look at that and we have to do something to address this. Because, again, we're talking about raising the standards, and we're not preparing our young people like the way we want to. So I'm a firm believer, and I believe that coming out of our basketball group that we supported just what you're proposing.

JACK EVANS: Well, with that, I'd like to bring this session to a close by thanking the members of this panel in a particular way. Each of these individuals is in fact someone who would be entitled to have the podium to him or herself for a session of this length. I choose to think that it's an indication of the importance that each of these people attaches to the NCAA academic reform activity, that they were willing to be here to share the podium and discuss their views on this topic. I thank each of them for being willing to be with us today for what I think has been an important and very constructive discussion. Thank you. 